\title{
The First Homoleptic Complex of Seven-Coordinated Osmium: Synthesis and Crystallographical Evidence of Pentagonal Bipyramidal Polyhedron of Heptacyanoosmate(IV)
}

\author{
Eugenia V. Peresypkina ${ }^{1,2}$, Anatolie Gavriluta ${ }^{3}$ and Kira E. Vostrikova ${ }^{1, *}$ \\ 1 Nikolaev Institute of Inorganic Chemistry SB RAS, Novosibirsk 630090, Russia; peresyp@niic.nsc.ru \\ 2 Novosibirsk State University, Novosibirsk 630090, Russia \\ 3 Laboratoire des Multimatériaux et Interfaces (UMR 5615), Université Claude Bernard Lyon 1, \\ 69622 Villeurbanne Cedex, France; gavriluta.anatolie@gmail.com \\ * Correspondence: vosk@niic.nsc.ru; Tel.: +7-383-316-5831
}

Academic Editors: Thomas Doert and Mathias Wickleder

Received: 9 August 2016; Accepted: 18 August 2016; Published: 23 August 2016

\begin{abstract}
The ligand exchange in $\left(n-\mathrm{Bu}_{4} \mathrm{~N}\right)_{2} \mathrm{Os}^{\mathrm{IV}} \mathrm{Cl}_{6}\left(n-\mathrm{Bu}_{4} \mathrm{~N}=\right.$ tetra- $n$-butylammonium) leads to the formation of the osmium(IV) heptacyanide, the first fully inorganic homoleptic complex of heptacoordinated osmium. The single-crystal X-ray diffraction (SC-XRD) study reveals the pentagonal bipyramidal molecular structure of the $\left[\mathrm{Os}(\mathrm{CN})_{7}\right]^{3-}$ anion. The latter being a diamagnetic analogue of the highly anisotropic paramagnetic synthon, $\left[\mathrm{Re}^{\mathrm{IV}}(\mathrm{CN})_{7}\right]^{3-}$ can be used for the synthesis of the model heterometallic coordination compounds for the detailed study and simulation of the magnetic properties of the low-dimensional molecular nanomagnets involving $5 d$ metal heptacyanides.
\end{abstract}

Keywords: osmium; heptacyanoosmate(IV); pentagonal bipyramid polyhedron

\section{Introduction}

The cyanide ligand occupies a special place in coordination chemistry. The exclusive nature of $\mathrm{CN}^{-}$species results from its capacity to act both as a $\sigma$-donor and a $\pi$-acceptor combined with its negative charge and ambidentate character. The ability of the cyano group to link different transition metal ions is applied for the construction of the diverse molecular assemblies. The history of cyanometallate chemistry began long before the creation of the coordination theory by Alfred Werner [1,2]. At the beginning of the 18th century, the German painter Diesbach by chance prepared a dark-blue pigment [3]. Almost 300 years later this compound, the mixed iron cyanide $\mathrm{Fe}^{\mathrm{III}}{ }_{4}\left[\mathrm{Fe}^{\mathrm{II}}(\mathrm{CN})_{6}\right]_{3} \cdot \mathrm{xH}_{2} \mathrm{O}$, named Prussian Blue became a focus of one of the most developed and extensively studied fields of coordination chemistry [4,5]. Cyanide-based compounds were found to act as photoswitchable magnetic solids [6-10], antidotes for radioactive poisoning [11], molecular sieves [12], hydrogen storage materials [13,14], high-temperature molecular magnets [15-17] and low-dimensional nanomagnets [18-22].

The research in the area of cyanides has been the subject of several reviews over the years [4,5,23-26]. However, the scarce amount of information on homoleptic osmium cyanide complexes is astounding [23,27-32]. Only cyanometallates(II) and (III) were structurally characterized to date despite the existence of higher oxidation states for osmium. Moreover, the homoleptic coordination compounds of Os with purely inorganic ligands comprise mainly hexaligated complexes, unlike its nearest neighbor of the $5 d$ row, Re, which demonstrates coordination numbers from six to eight [33-36]. The recent isolation of heptacyanotungstate(IV) as a salt $\left(n-\mathrm{Bu}_{4} \mathrm{~N}\right)_{3}\left[\mathrm{~W}^{\mathrm{IV}}(\mathrm{CN})_{7}\right]$ $\left(n-\mathrm{Bu}_{4} \mathrm{~N}=\right.$ tetra- $n$-butylammonium) [37] has widened the family of rare heptacyanometallate anions. 
Here, we present the pioneering results in osmium coordination chemistry involving the synthesis and exhaustive structural study of the $\left(n-\mathrm{Bu}_{4} \mathrm{~N}\right)_{3}\left[\mathrm{Os}^{\mathrm{IV}}(\mathrm{CN})_{7}\right],(\mathbf{1})$ - the only homoleptic complex with heptacoordinated osmium (Figure 1), which also represents the first example of fully characterized cyanoosmate(IV).

\section{Experimental}

\subsection{Materials and Physical Methods}

Dry, stored over molecular sieves solvents, $\mathrm{OsO}_{4}(99.8 \%)$ and tetra- $n$-butylammonium salts were purchased from Johnson Matthey and Sigma-Aldrich, respectively. The $\left(n-\mathrm{Bu}_{4} \mathrm{~N}\right)_{2}\left[\mathrm{OsCl}_{6}\right]$ was obtained by the precipitation from aqueous solution of $\mathrm{H}_{2}\left[\mathrm{OsCl}_{6}\right.$ ] [38] using $\left(n-\mathrm{Bu}_{4} \mathrm{~N}\right) \mathrm{Cl}$. Elemental analyses were performed by means of a Euro-Vector 3000 analyzer (Eurovector, Redavalle, Italy). IR spectra were recorded in the solid state with a NICOLET spectrophotometer (Thermo Electron Scientific Instruments LLC, Madison, WI, USA) in the $375-4000 \mathrm{~cm}^{-1}$ range. Mass spectra were obtained using an ion trap mass spectrometer (LCQ, Thermo, Bremen, Germany) equipped with an electro spray (ESI) ion source in the positive and negative ion mode. The spray voltage for the positive and negative ion mode is respectively $4 \mathrm{kV}$ and $-3 \mathrm{kV}$. The capillary transfer temperature is $200{ }^{\circ} \mathrm{C}$. Magnetic susceptibility data were collected over a 2-300 K temperature range with an applied field of $5 \mathrm{~T}$ using a MPMS SQUID magnetometer (Quantum Design, Inc., San Diego, CA, USA). The raw data were corrected for the sample holder and for the diamagnetic contribution of the constituent atoms using Pascal's constants [39].

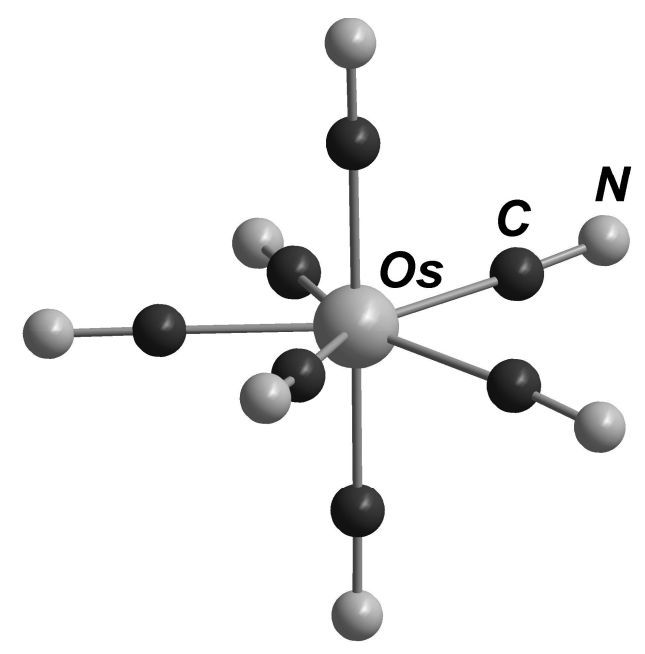

Figure 1. Structure of pentagonal bipyramidal $\left[\mathrm{Os}(\mathrm{CN})_{7}\right]^{3-}$ complex in $\mathbf{1}$.

\subsection{Synthesis}

$\left(\mathrm{Bu}_{4} \mathrm{~N}\right)_{3}\left[\mathrm{Os}(\mathrm{CN})_{7}\right] \cdot 0.5 \mathrm{H}_{2} \mathrm{O}(\mathbf{1})$. A mixture of $\left(n-\mathrm{Bu}_{4} \mathrm{~N}\right)_{2}\left[\mathrm{OsCl}_{6}\right](1 \mathrm{~g}, 1.13 \mathrm{mmol})$ and $\left(n-\mathrm{Bu}_{4} \mathrm{~N}\right) \mathrm{CN}$ from freshly opened bottle $(2.15 \mathrm{~g}, 8 \mathrm{mmol})$ in dimethylformamide (DMF) $(3 \mathrm{~mL})$ was heated at $100{ }^{\circ} \mathrm{C}$ for $16 \mathrm{~h}$. After the cooling to ambient temperature the green-bluish solution was reduced in volume to $1 \mathrm{~mL}$ using rotary evaporator, and tetrahydrofuran (THF) $(10 \mathrm{~mL})$ was added to the reaction mixture. The clear yellow crystalline product was formed after two days, which was filtered off and washed with $3 \times 2 \mathrm{~mL}$ of THF. Yield: $0.208 \mathrm{~g}(17 \%)$. (Found: C, 59.8; $\mathrm{H}$, 10.0; $\mathrm{N}, 12.7$. $\mathrm{C}_{55} \mathrm{H}_{109} \mathrm{~N}_{10} \mathrm{O}_{0.5} \mathrm{Os}\left(M_{\mathrm{w}}=1108.72\right)$ : requires $\mathrm{C}, 59.47 ; \mathrm{H}, 9.9 ; \mathrm{N}, 12.62 \%$.) ESI-MS in MeCN (negative): $m / z 1956\left\{\left(n-\mathrm{Bu}_{4} \mathrm{~N}\right)_{5}\left[\mathrm{Os}(\mathrm{CN})_{7}\right]_{2}\right\}^{-}, 1931\left\{\left(n-\mathrm{Bu}_{4} \mathrm{~N}\right)_{5}\left[\mathrm{Os}(\mathrm{CN})_{7}\right]\left[\mathrm{Os}(\mathrm{CN})_{6}\right]\right\}^{-}, 858$ $\left\{\left(n-\mathrm{Bu}_{4} \mathrm{~N}\right)_{2}\left[\mathrm{Os}(\mathrm{CN})_{7}\right]\right\}^{-}, 832\left\{\left(n-\mathrm{Bu}_{4} \mathrm{~N}\right)_{2}\left[\mathrm{Os}(\mathrm{CN})_{6}\right]\right\}^{-}, 294\left\{\left[\mathrm{Os}(\mathrm{CN})_{4}\right]\right\}^{-}$. ESI-MS in $\mathrm{CH}_{3} \mathrm{CN}$ (positive): $m / z 1343\left\{\left(n-\mathrm{Bu}_{4} \mathrm{~N}\right)_{4}\left[\mathrm{Os}(\mathrm{CN})_{7}\right]\right\}^{+}, 1317\left\{\left(n-\mathrm{Bu}_{4} \mathrm{~N}\right)_{4}\left[\mathrm{Os}(\mathrm{CN})_{6}\right]\right\}^{+} . \mathrm{IR}, \mathrm{cm}^{-1}: 418,464,500,515,603,734,799$, 
$884,1028,1059,1108,1154,1382,1463,1487,1651,2077,2108,2131,2875,2962,3465$. Crystals suitable for X-ray diffraction study were obtained by slow diffusion of THF vapors in MeCN solution of 1.

\subsection{X-ray Crystallography}

The diffraction experiment for $\mathbf{1}$ was performed on a SuperNova diffractometer equipped with Atlas detector and a micro-source $\mathrm{CuK} \alpha$ tube. The absorption corrections were applied empirically using equivalent reflections [40]. The structure was solved and refined with SHELX-97 program [41] using least squares method on $|F|^{2}$ in anisotropic approximation for non- $\mathrm{H}$ atoms. More details are presented in Table 1. Hydrogen atoms were located in idealized positions and refined in isotropic approximation using the riding on pivot model. One of the $n$-butyl groups is disordered over three close positions with $0.45,0.35$ and 0.2 occupancies. The disordered atoms were refined in isotropic approximation, and some geometric restraints have to be applied for the disordered group. Powder X-ray diffraction measurements were performed with $\mathrm{Cu}-\mathrm{K} \alpha$ radiation $(\lambda=1.5418 \AA)$ using an PAN analytical X'Pro powder diffractometer (PANalytical Inc., Almelo, The Netherlands).

Table 1. Single-crystal X-ray diffraction analysis data and structure refinement parameters of $\mathbf{1}$.

\begin{tabular}{|c|c|}
\hline \multicolumn{2}{|c|}{ Crystal Data } \\
\hline Chemical formula & $\left(\mathrm{C}_{16} \mathrm{H}_{36} \mathrm{~N}\right)_{3}\left(\mathrm{C}_{7} \mathrm{~N}_{7} \mathrm{Os}\right)\left(\mathrm{H}_{2} \mathrm{O}\right)_{0.5}$ \\
\hline$M_{r}$ & 1108.72 \\
\hline Crystal system, space group & Monoclinic, $P 2_{1} / c$ \\
\hline Temperature $(\mathrm{K})$ & 150 \\
\hline$a, b, c(\AA)$ & $22.8582(3), 23.0300(4), 23.0373(3)$ \\
\hline$\beta\left({ }^{\circ}\right)$ & $90.840(1)$ \\
\hline$V\left(\AA^{3}\right)$ & $12126.1(3)$ \\
\hline Z & 8 \\
\hline$F(000)$ & 4712 \\
\hline Radiation type & $\mathrm{Cu} \mathrm{K \alpha}$ \\
\hline$\mu\left(\mathrm{mm}^{-1}\right)$ & 4.28 \\
\hline$D_{\text {calcd }}\left(\mathrm{g} \cdot \mathrm{cm}^{-1}\right)$ & 1.215 \\
\hline Crystal shape & rod \\
\hline Color & pale yellow \\
\hline Crystal size (mm) & $0.11 \times 0.07 \times 0.02$ \\
\hline \multicolumn{2}{|c|}{ Data Collection } \\
\hline \multicolumn{2}{|c|}{ Super Nova diffractometer (Atlas), Single source at offset } \\
\hline Absorption correction & Multi-scan \\
\hline$T_{\min }, T_{\max }$ & $0.900,1.000$ \\
\hline $\begin{array}{l}\text { Number of measured, independent and observed } \\
\qquad[I>2 \sigma(I)] \text { reflections }\end{array}$ & $42839,23015,14167$ \\
\hline$R_{\text {int }}$ & 0.056 \\
\hline$(\sin \theta / \lambda)_{\max }\left(\AA^{-1}\right)$ & 0.619 \\
\hline \multicolumn{2}{|c|}{ Refinement } \\
\hline$R\left[F^{2}>2 \sigma\left(F^{2}\right)\right], w R\left(F^{2}\right), S$ & $0.054,0.142,0.93$ \\
\hline No. of reflections & 23015 \\
\hline No. of parameters & 1234 \\
\hline No. of restraints & 15 \\
\hline H-atom treatment & H-atom parameters constrained \\
\hline$\left.\Delta\rangle_{\max }, \Delta\right\rangle_{\min }\left(\mathrm{e} \AA^{-3}\right)$ & $4.39,-1.51$ \\
\hline
\end{tabular}

\section{Results and Discussion}

\subsection{Synthesis and Characterization}

The number of osmium homoleptic complex cyanides is limited to the hexacoordinated coordination compounds of two metal oxidation states-two and three. If the hexacyanoosmate(II) 
was known for a long time [42], its crystal structure having been determined for the sodium salt $\mathrm{Na}_{4}\left[\mathrm{Os}^{\mathrm{II}}(\mathrm{CN})_{6}\right] \cdot 10 \mathrm{H}_{2} \mathrm{O}[28]$, the paramagnetic hexacyanoosmate(III) was only recently structurally characterized and magnetically investigated as $\mathrm{Ph}_{4} \mathrm{P}^{+}$salt [30] despite the successful synthesis of $n$-Bu ${ }_{4} \mathrm{~N}$ analog almost 50 years ago [43]. Both paramagnetic cyanides were prepared starting from the diamagnetic precursor $\mathrm{K}_{4}\left[\mathrm{Os}^{\mathrm{II}}(\mathrm{CN})_{6}\right] \cdot 3 \mathrm{H}_{2} \mathrm{O}$.

As cyanide is a stronger ligand than halides, a promising route to cyanometallates is an exchange of the halides in the corresponding $\left[\mathrm{MHal}_{n}\right]^{\mathrm{m}-}$ complexes by the $\mathrm{CN}^{-}$anion (Scheme 1). Inspired by a successful ligand exchange preparation of $\left(n-\mathrm{Bu}_{4} \mathrm{~N}\right)_{3}\left[\mathrm{Re}^{\mathrm{IV}}(\mathrm{CN})_{7}\right]$ performed by M.V. Bennett and J.R. Long [36], we have adapted this procedure for the synthesis of osmium cyanides starting from $\left(n-\mathrm{Bu}_{4} \mathrm{~N}\right)_{2} \mathrm{Os}^{\mathrm{IV}} \mathrm{Cl}_{6}$. Indeed, after the addition of the cyanide agent to a cold solution of $\left(n-\mathrm{Bu}_{4} \mathrm{~N}\right)_{2} \mathrm{Os}^{\mathrm{IV}} \mathrm{Cl}_{6}$ in dry DMF followed by the heating of the reaction mixture at $100{ }^{\circ} \mathrm{C}$ for $16 \mathrm{~h}$, a dark green-bluish solution was obtained (see Experimental Section). The layering of THF on the reaction mixture gave a batch of clear yellow crystals, which according to both elemental and SC-XRD analyses were tetra- $n$-butylammonium heptacyanoosmate(IV) hemihydrate, $\left(n-\mathrm{Bu}_{4} \mathrm{~N}\right)_{3}\left[\mathrm{Os}(\mathrm{CN})_{7}\right] \cdot 0.5 \mathrm{H}_{2} \mathrm{O}(\mathbf{1})$. In the IR spectrum of 1 (Supplementary Materials, Figure S1), the characteristics of the $\mathrm{H}_{2} \mathrm{O} v_{\mathrm{OH}}$ stretch at $3465 \mathrm{~cm}^{-1}$ and a set of three cyanide stretches at 2131,2108, $2077 \mathrm{~cm}^{-1}$ are present which are in excellent agreement with the data for $\left(n-\mathrm{Bu}_{4} \mathrm{~N}\right)_{3}\left[\operatorname{Re}(\mathrm{CN})_{7}\right]$ [36] $\left(2135 \mathrm{sh}, 2114\right.$ and $\left.2074 \mathrm{~cm}^{-1}\right)$ (Supplementary Materials, Figure S2). Magnetic measurements at 2-300 K have confirmed the diamagnetic character of the compound.

$$
\begin{gathered}
\mathrm{K}_{\mathrm{m}}\left[\mathrm{MHal}_{6}\right]+\mathrm{mBu}_{4} \mathrm{~N}(\mathrm{Hal}) \rightarrow\left(\mathrm{Bu}_{4} \mathrm{~N}\right)_{\mathrm{m}}\left[\mathrm{MHal}_{6}\right] \\
\left(\mathrm{Bu}_{4} \mathrm{~N}\right)_{\mathrm{m}}\left[\mathrm{MHal}_{6}\right]+(6+\mathrm{x}) \mathrm{Bu}_{4} \mathrm{~N}(\mathrm{CN}) \rightarrow\left(\mathrm{Bu}_{4} \mathrm{~N}\right)_{\mathrm{m}+\mathrm{x}}\left[\mathrm{M}(\mathrm{CN})_{6+\mathrm{x}}\right]
\end{gathered}
$$

Scheme 1. Ligand exchange procedure.

\subsection{Crystal Structure Description}

X-ray analysis of a single crystal of $\mathbf{1}$ revealed that both symmetrically non-equivalent $\left[\mathrm{Os}(\mathrm{CN})_{7}\right]^{3-}$ anions adopt the pentagonal bipyramidal geometry (Figure 2). Bond lengths and bond angles for the anions are summarized in Table 2 . The complexes have $C_{1}$ symmetry being in general position of the monoclinic $P 2_{1} / c$ space group. However, the geometry of the coordination polyhedra is almost undistorted. The carbon atoms of the five equatorial cyanide ligands form a planar equilateral pentagon (deviations of the $\mathrm{C}$ atoms from the equatorial plane are $\sim 0.15^{\circ}$ ) with angular distortion that does not exceed $2^{\circ}$ are compared with the ideal value $360^{\circ} / 5=72^{\circ}$ for C-Os-C angles. The axial atoms are slightly tilted with respect to the equatorial plane; the maximal distortion is $\sim 4^{\circ}$. The Os-C distances fall within the range of 2.046(7)-2.093(7) $\AA$ and the apical Os-C distances vary in the range of 2.043(8)-2.090(8) $\AA$. These values are comparable to those observed in related cyanide complexes $\left(n-\mathrm{Bu}_{4} \mathrm{~N}\right)_{3}\left[\operatorname{Re}(\mathrm{CN})_{7}\right](2.064(10)-2.123(11) \AA)$ and $\mathrm{K}_{4}\left[\operatorname{Re}(\mathrm{CN})_{7}\right] \cdot 2 \mathrm{H}_{2} \mathrm{O}(2.077(3)-2.099(6)$ [36] and 2.077(3) ̊̊) [44], respectively.

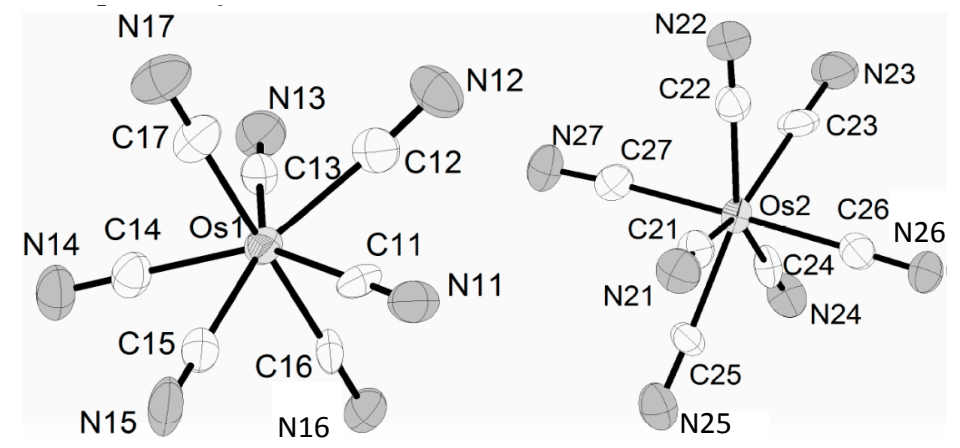

Figure 2. The numbering scheme in two independent molecules of the $\left[\mathrm{Os}(\mathrm{CN})_{7}\right]^{3-}$ complex. 
Table 2. Some geometrical characteristics of $\left[\mathrm{Os}(\mathrm{Cn})_{7}\right]^{3-}$ in $\mathbf{1}$.

\begin{tabular}{llll}
\hline Bond & Bond Length, A & Bond & Bond Length, A \\
\hline Os1-C11 & $2.093(7)$ & Os2-C21 & $2.070(6)$ \\
Os1-C12 & $2.066(8)$ & Os2-C22 & $2.079(7)$ \\
Os1-C13 & $2.046(8)$ & Os2-C23 & $2.046(7)$ \\
Os1-C14 & $2.054(7)$ & Os2-C24 & $2.055(6)$ \\
Os1-C15 & $2.066(8)$ & Os2-C25 & $2.072(6)$ \\
Os1-C16 & $2.043(8)$ & Os2-C26 & $2.060(7)$ \\
Os1-C17 & $2.090(8)$ & Os2-C27 & $2.078(7)$ \\
N11-C11 & $1.124(10)$ & N21-C21 & $1.155(9)$ \\
N12-C12 & $1.173(10)$ & N22-C22 & $1.142(9)$ \\
N13-C13 & $1.164(10)$ & N23-C23 & $1.171(9)$ \\
N14-C14 & $1.161(10)$ & N24-C24 & $1.158(8)$ \\
N15-C15 & $1.141(10)$ & N25-C25 & $1.153(9)$ \\
N16-C16 & $1.180(10)$ & N26-C26 & $1.166(9)$ \\
N17-C17 & $1.114(10)$ & N27-C27 & $1.145(9)$ \\
\hline Bond Angle & Angle, ${ }^{\circ}$ & Bond Angle & Angle, \\
\hline C11-Os1-C12 & $71.6(3)$ & C21-Os2-C22 & $73.3(3)$ \\
C12-Os1-C13 & $71.3(3)$ & C22-Os2-C23 & $72.9(3)$ \\
C13-Os1-C14 & $73.9(3)$ & C23-Os2-C24 & $72.9(3)$ \\
C14-Os1-C15 & $73.1(3)$ & C24-Os2-C25 & $72.6(3)$ \\
C15-Os1-C11 & $71.9(3)$ & C25-Os2-C21 & $70.9(3)$ \\
C16-Os1-C17 & $179.3(3)$ & C26-Os2-C27 & $178.7(3)$ \\
\hline
\end{tabular}

The $\left[\mathrm{Os}(\mathrm{CN})_{7}\right]^{3-}$ anions are well separated from each other by a cationic surrounding involving six $n-\mathrm{Bu}_{4} \mathrm{~N}^{+}$, each tetra- $n$-butylammonium unit (Supplementary Materials, Figure S4) having two nearest heptacyanoosmate moieties (Figure 2). Only one complex $\left[\mathrm{Os}(\mathrm{CN})_{7}\right]^{3-}$ anion, comprising a Os(1) center, is involved in a hydrogen bonding with a water molecule, forming an intermolecular N ... O contact of 2.88(1) $\AA$.

The powder diffractogram of the polycrystalline sample for $\mathbf{1}$ corresponds well to the diffractogram calculated from the single-crystal data (Figure 3).

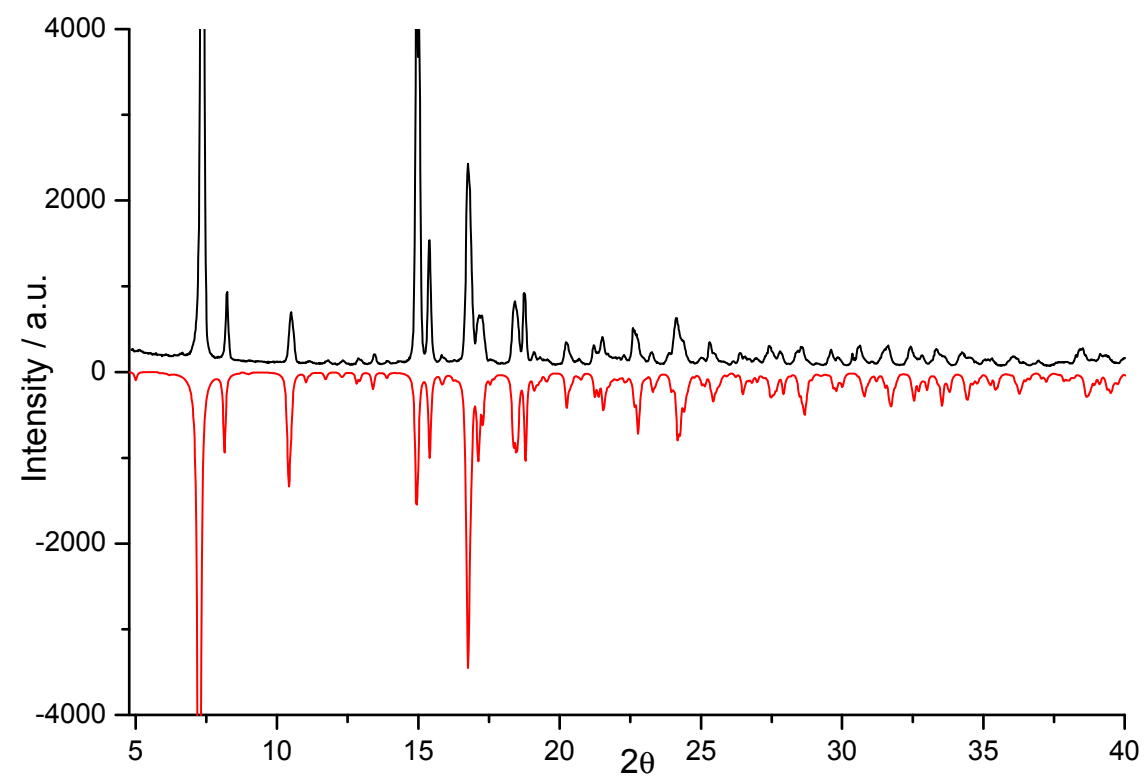

Figure 3. Calculated from the single-crystal diffraction data (red) and experimental powder XRD (black) diffractograms for $\mathbf{1}$. 
To the best of our knowledge, it is the first structurally characterized heptacoordinated osmium complex involving seven equivalent ligands. The coordination number of seven and more is known for the Os central atom only in carbonyl-containing clusters as well as heteroleptic mononuclear hydrides of the metal [45-47]. The neutral osmium heptafluoride, reported by O. Glemser et al. [48], was not reproduced by H. Shorafa and K. Seppelt later [49]. Moreover, the theoretical calculations performed by A. K. Srivastava and N. Misra demonstrate that $\left[\mathrm{OsF}_{7}\right]$ is unstable and dissociates into $\mathrm{OsF}_{6}$ and $\mathrm{F}$ fragments, unlike its hypothetical anion $\left[\mathrm{OsF}_{7}\right]^{-}$, which should be stable with respect to loss of fluoride [50].

\subsection{Magnetic Properties}

Complex $\mathbf{1}$ is diamagnetic (see Supplementary Materials, Figure S5) due to the $\mathrm{d}^{4}$ electronic configuration of the $\mathrm{Os}^{4+}$ ion in the pentagonal bipyramidal environment (Figure 4). However, being a diamagnetic analogue of the highly anisotropic paramagnetic complex, $\left[\operatorname{Re}^{\mathrm{IV}}(\mathrm{CN})_{7}\right]^{3-}$ can be used for the synthesis of the model heterometallic coordination compounds for the detail study and simulation of the magnetic properties of low-dimensional molecular nanomagnets involving $5 d$ metal heptacyanides. For example, in the case of the single-molecule magnet, $\mathrm{Et}_{4} \mathrm{~N}\left[\mathrm{Mn}^{\mathrm{III}}\left(5-\mathrm{Br}\right.\right.$-salen) $\mathrm{MeOH}_{2}\left[\mathrm{Ru}^{\mathrm{III}}(\mathrm{CN})_{6}\right]$ [51-53], an isostructural complex incorporating diamagnetic $\left[\mathrm{Ir}^{\mathrm{III}}(\mathrm{CN})_{6}\right]^{3-}$, was used to determine the parameters of magnetic anisotropy for the complex [Mn $\left.{ }^{\mathrm{III}}(5-\mathrm{Br}-\mathrm{salen}) \mathrm{MeOH}\right]^{+}$, which is a part of the former [54].

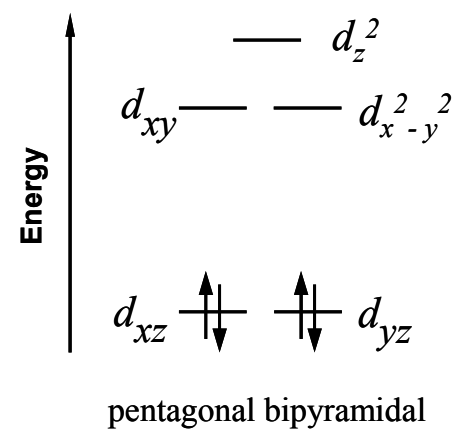

Figure 4. The qualitative d-orbital energy-splitting diagram for pentagonal bipyramidal geometry and the ground-state electronic configuration of $\mathbf{1}$.

\section{Conclusions and Perspectives}

The ligand exchange process in $\left(n-\mathrm{Bu}_{4} \mathrm{~N}\right)_{2} \mathrm{Os}^{\mathrm{IV}} \mathrm{Cl}_{6}$ was used for the synthesis of the osmium(IV) heptacyanide. The latter, prepared as its tetra- $n$-butylammonium salt, is the first structurally characterized purely inorganic homoleptic complex anion of osmium involving seven ligands. The pentagonal bipyramidal structure of the anion $\left[\mathrm{Os}(\mathrm{CN})_{7}\right]^{3-}$ was confirmed by single-crystal $\mathrm{XRD}$. The discovery of compound $\mathbf{1}$ is an outstanding result in the coordination chemistry of osmium.

We are working now on the development of an improved synthetic protocol in order to obtain 1 in higher yield which will allow us to obtain more information about their properties both in solid and solution. Furthermore, as $\left[\mathrm{Os}^{\mathrm{IV}}(\mathrm{CN})_{7}\right]^{3-}$ is a diamagnetic analogue of $\left[\operatorname{Re}^{\mathrm{IV}}(\mathrm{CN})_{7}\right]^{3-}$, it therefore can be used for the synthesis of the model systems for $\left[\left(\mathrm{M}^{\text {para }} \mathrm{L}\right) \operatorname{Re}(\mathrm{CN})_{7}\right]^{\mathrm{m}-}$, the highly anisotropic heterobimetallic molecular magnetic materials, to experimentally determine the magnetic anisotropy contribution of their paramagnetic constituent $\left[\mathrm{M}^{\mathrm{para}} \mathrm{L}\right]^{\mathrm{n}+}$. In the near future we have the intention to synthesize 1D polymer $\left(\mathrm{Ph}_{4} \mathrm{P}\right)_{2}\left[\mathrm{Mn}(\right.$ acacen $\left.) \operatorname{Re}(\mathrm{CN})_{7}\right]$, a rhenium congener of the recently studied single-chain magnet $\left(\mathrm{Ph}_{4} \mathrm{P}\right)_{2}\left[\mathrm{Mn}(\right.$ acacen $\left.) \mathrm{Os}(\mathrm{CN})_{6}\right]$ [22] and its model compound $\left(\mathrm{Ph}_{4} \mathrm{P}\right)_{2}\left[\mathrm{Mn}\right.$ (acacen)Os $\left.(\mathrm{CN})_{7}\right]$ for better understanding the magnetic properties of the former. 
Supplementary Materials: The following are available online at http:/ www.mdpi.com/2073-4352/6/9/102/s1, Figure S1: IR spectrum of $\left(n-\mathrm{Bu}_{4} \mathrm{~N}\right)_{3}\left[\mathrm{Os}(\mathrm{CN})_{7}\right] \cdot 0.5 \mathrm{H}_{2} \mathrm{O}(1)$ (reflectance), Figure S2: $\mathrm{CN}^{-}$valance stretch region in the IR spectra of: $\left(n-\mathrm{Bu}_{4} \mathrm{~N}\right)_{3}\left[\mathrm{Os}(\mathrm{CN})_{7}\right]\left(\mathrm{H}_{2} \mathrm{O}\right)_{0.5}($ red $)$ and $\left(n-\mathrm{Bu}_{4} \mathrm{~N}\right)_{3}\left[\operatorname{Re}(\mathrm{CN})_{7}\right]$ (black) (reflectance), Figure S3: MS-ESI spectrum of the reaction mixture of 1: (a)-cationic part; (b) and (c)-anionic part, Figure S4: The crystal packing in 1, Figure S5: The temperature dependence for the effective magnetic moment of the polycrystalline sample of 1 . CCDC $1020688\left(\mathrm{Bu}_{4} \mathrm{~N}\right)_{3}\left[\mathrm{Os}(\mathrm{CN})_{7}\right] \cdot 0,5 \mathrm{H}_{2} \mathrm{O}$ contains the supplementary crystallographic data for this paper. These data can be obtained free of charge from The Cambridge Crystallographic Data Centre via www.ccdc.cam.ac.uk/ data_request/cif.

Acknowledgments: This work was supported in part by European Commission (PIIFR-GA-2011-911689) and RFBR (gr. 08-03-00459-a). Eugenia V. Peresypkina thanks Michael Bodensteiner for access to the SuperNova diffractometer. We express our gratitude to Ruben Checa for the magnetic measurements.

Author Contributions: Kira E. Vostrikova conceived, designed and performed the experiment, as well as wrote the paper; Anatolie Gavriluta reproduced some experiments and grew the single crystals; Eugenia V. Peresypkina performed the crystallographic studies and participated in the article redaction.

Conflicts of Interest: The authors declare no conflict of interest.

\section{References}

1. Werner, A. Beitrag zur Konstitution anorganischer Verbindungen. Z. Anorg. Allg. Chem. 1893, 3, $267-330$. [CrossRef]

2. Constable, E.C.; Housecroft, C.E. Coordination chemistry: The scientific legacy of Alfred Werner. Chem. Soc. Rev. 2013, 42, 1429-1439. [CrossRef] [PubMed]

3. Woodward, J. Praeparatio Caerulei Prussiaci. Philos. Trans. 1724, 33, 15-17. [CrossRef]

4. Verdaguer, M.; Bleuzen, A.; Marvaud, V.; Vaissermann, J.; Seuleiman, M.; Desplanches, C.; Scuiller, A.; Train, C.; Garde, R.; Gelly, G.; et al. Molecules to build solids: high TC molecule-based magnets by design and recent revival of cyano complexes chemistry. Coord. Chem Rev. 1999, 192, 1023-1047. [CrossRef]

5. Verdaguer, M.; Girolami, G.S. Magnetic Prussian Blue Analogs. In Magnetism: Molecules to Materials, V; Miller, J.S., Drillon, M., Eds.; Wiley-VCH Verlag GmbH and Co. KGaA: Weinheim, Germany, 2005; Volume 3, pp. 283-346.

6. Sato, O.; Iyoda, T.; Fujishima, A.; Hashimoto, K. Photoinduced Magnetization of a Cobalt-Iron Cyanide. Science 1996, 272, 704-705. [CrossRef] [PubMed]

7. Bleuzen, A.; Marvaud, V.; Mathoniere, C.; Sieklucka, B.; Verdaguer, M. Photomagnetism in Clusters and Extended Molecule-Based Magnets. Inorg. Chem. 2009, 48, 3453-3466.

8. Carvajal, M.-A.; Caballol, R.; de Graaf, C. Insights on the photomagnetism in copper octacyanomolybdates. Dalt. Trans. 2011, 40, 7295-7303. [CrossRef] [PubMed]

9. Lejeune, J.; Cafun, J.-D.; Fornasieri, G.; Brubach, J.-B.; Creff, G.; Roy, P.; Bleuzen, A. Microscopic Origin for Multistability in a Photomagnetic CoFe Prussian Blue Analogue. Eur. J. Inorg. Chem. 2012, 3980-3983.

10. Mondal, A.; Chamoreau, L.-M.; Li, Y.; Journaux, Y.; Seuleiman, M.; Lescouëzec, R. W-Co discrete complex exhibiting photo- and thermo-induced magnetization. Chem. Eur. J. 2013, 19, 7682-7685. [CrossRef] [PubMed]

11. U.S. Food and Drug Administration. Available online: http://www.fda.gov/Drugs/ EmergencyPreparedness/BioterrorismandDrugPreparedness/ucm130334.htm (accessed on 28 May 2016).

12. Boxhoorn, G.; Moolhuysen, J.; Coolegem, J.G.F.; Van Santen, R.A. Cyanometallates: An underestimated class of molecular sieves. J. Chem. Soc. Chem. Commun. 1985, 19, 1305-1307. [CrossRef]

13. Chapman, K.W.; Southon, P.D.; Weeks, C.L.; Kepert, C.J. Reversible hydrogen gas uptake in nanoporous Prussian Blue analogues. Chem. Commun. 2005, 26, 3322-3324. [CrossRef] [PubMed]

14. Kaye, S.S.; Long, J.R. Hydrogen Storage in the Dehydrated Prussian Blue Analogues $\mathrm{M}_{3}\left[\mathrm{Co}(\mathrm{CN})_{6}\right]_{2}$ (M = Mn, Fe, Co, Ni, Cu, Zn). J. Am. Chem. Soc. 2005, 127, 6506-6507. [CrossRef] [PubMed]

15. Ferlay, S.; Mallah, T.; Ouahes, R.; Veillet, P.; Verdaguer, M. A room-temperature organometallic magnet based on Prussian blue. Nature 1995, 378, 701-703. [CrossRef]

16. Entley, W.R.; Girolami, G.S. High-temperature molecular magnets based on cyanovanadate building blocks: Spontaneous magnetization at 230 K. Science 1995, 268, 397-400. [CrossRef] [PubMed]

17. Holmes, S.M.; Girolami, G.S. Sol-Gel Synthesis of $\mathrm{KV}^{\mathrm{II}}\left[\mathrm{Cr}^{\mathrm{III}}(\mathrm{CN})_{6}\right] \cdot 2 \mathrm{H}_{2} \mathrm{O}$ : A crystalline molecule-based magnet with a magnetic ordering temperature above $100{ }^{\circ} \mathrm{C}$. J. Am. Chem. Soc. 1999, 121, 5593-5594. [CrossRef] 
18. Wang, X.-Y.; Avendaňo, C.; Dunbar, K.R. Molecular magnetic materials based on 4d and 5d transition metals. Chem. Soc. Rev. 2011, 40, 3213-3238. [CrossRef] [PubMed]

19. Pedersen, K.S.; Bendix, J.; Clérac, R. Single-molecule magnet engineering: Building-block approaches. Chem. Commun. 2014, 50, 4396-4415. [CrossRef] [PubMed]

20. Zhang, W.-X.; Breedlove, B.; Ishikawa, R.; Yamashita, M. Single-chain magnets: Beyond the Glauber model. RSC Adv. 2013, 3, 3772-3798. [CrossRef]

21. Rams, M.; Peresypkina, E.V.; Mironov, V.S.; Wernsdorfer, W.; Vostrikova, K.E. Magnetic Relaxation of 1D Coordination Polymers $(\mathrm{X})_{2}\left[\mathrm{Mn}(\right.$ acacen $\left.) \mathrm{Fe}(\mathrm{CN})_{6}\right], \mathrm{X}=\mathrm{Ph}_{4} \mathrm{P}^{+}, \mathrm{Et}_{4} \mathrm{~N}^{+}$. Inorg. Chem. 2014, 53, 10291-10300. [CrossRef] [PubMed]

22. Peresypkina, E.V.; Majcher, A.; Rams, M.; Vostrikova, K.E. A single chain magnet involving hexacyanoosmate. Chem. Commun. 2014, 50, 7150-7153. [CrossRef] [PubMed]

23. Sharpe, A.C. The Chemistry of Cyano Complexes of the Transition Metals; Academic Press: New York, NY, USA, 1976.

24. Babel, D. Magnetism and Structure: Model Studies on Transition Metal Fluorides and Cyanides. Comments Inorg. Chem. 1986, 5, 285-320. [CrossRef]

25. Dunbar, K.R.; Heintz, R.A. Chemistry of Transition Metal Cyanide Compounds: Modern Perspectives. In Progress in Inorganic Chemistry; Karlin, K.D., Ed.; John Wiley \& Sons, Inc.: Hoboken, NJ, USA, 1997; Volume 45, pp. 283-391.

26. Shatruk, M.; Avendaňo, C.; Dunbar, K.R. Cyanide-Bridged Complexes of Transition Metals: A Molecular Magnetism Perspective. In Progress in Inorganic Chemistry; Karlin, K.D., Ed.; John Wiley \& Sons, Inc.: Hoboken, NJ, USA, 2009; Volume 56, pp. 155-334.

27. Curtis, J.C.; Meyer, T.J. Outer-sphere charge transfer in mixed-metal ion pairs. Inorg. Chem. 1982, 21, 1562-1571. [CrossRef]

28. Gentil, L.A.; Navaza, A.; Olabe, J.A.; Rigotti, G.E. The crystal and molecular structure of sodium hexacyanoosmate(II) decahydrate and related hexacyanometalate complexes. Inorg. Chim. Acta 1991, 179, 89-96. [CrossRef]

29. Kang, H.W.; Moran, G.; Krausz, E. Magnetic circular dichroism spectroscopy of the hexacyano complexes of $\mathrm{Ru}(\mathrm{III})$ and Os(III). Inorg. Chim. Acta 1996, 249, 231-235. [CrossRef]

30. Albores, P.; Slep, L.D.; Baraldo, L.M.; Baggio, R.; Garland, M.T.; Rentschler, E. Crystal Structure and Electronic and Magnetic Properties of Hexacyanoosmate(III). Inorg. Chem. 2006, 45, 2361-2363. [CrossRef] [PubMed]

31. Van den Heuvel, W.; Hendrickx, M.F.A.; Ceulemans, A.A. CASPT2 Study of the Electronic Spectrum of Hexacyanoosmate(III). Inorg. Chem. 2007, 46, 8032-8037. [CrossRef] [PubMed]

32. Vostrikova, K.E.; Peresypkina, E.V. Facile Preparation of Paramagnetic Ru ${ }^{\text {III }}$ and Os ${ }^{\text {III }}$ Hexacyanides. Eur. J. Inorg. Chem. 2011, 6, 811-815. [CrossRef]

33. Pombeiro, J.L.; Guedes da Silva, M.F.C.; Crabtree, R.H. Technetium \& Rhenium: Inorganic \& Coordination Chemistry. In Encyclopedia of Inorganic and Bioinorganic Chemistry; Wiley-VCH Verlag GmbH and Co. KGaA: Weinheim, Germany, 2006.

34. Alberto, R. Comprehensive Coordination Chemistry II; Elsevier: Amsterdam, The Netherlands, 2004; Volume V, p. 127.

35. Colton, R.; Peacock, R.D.; Wilkinson, G. 275. Complex cyanides of rhenium. J. Chem. Soc. 1960, 1374-1378. [CrossRef]

36. Bennett, M.V.; Long, J.R. New Cyanometalate Building Units: Synthesis and Characterization of $\left[\operatorname{Re}(\mathrm{CN})_{7}\right]^{3-}$ and $\left[\operatorname{Re}(\mathrm{CN})_{8}\right]^{3-}$. J. Am. Chem. Soc. 2003, 125, 2394-2395. [CrossRef] [PubMed]

37. Birk, F.J.; Pinkowicz, D.; Dunbar, K.R. The Heptacyanotungstate(IV) Anion: A New 5d ransition-Metal Member of the Rare Heptacyanometallate Family of Anions. Angew. Chem. Int. Ed. 2016, 55, 1-4.

38. Synthesis of the Complex Compounds of Platinum Group; Cherniaev, I.I. (Ed.) Publishing House "Nauka": Moscow, Russia, 1964; p. 294.

39. Bain, G.A.; Berry, J.F. Diamagnetic Corrections and Pascal's Constants. J. Chem. Educ. 2008, 85, 532-536. [CrossRef]

40. Clark, R.C.; Reid, J.S. The analytical calculation of absorption in multifaceted crystals. Acta Cryst. 1995, A51, 887-897. [CrossRef]

41. Sheldrick, G.M. A short history of SHELX. Acta Cryst. A 2008, 64, 112-122. [CrossRef] [PubMed] 
42. Krauss, A.; Schrader, G. Zur Kenntnis der Cyanverbindungen der Platinmetalle. III. Über die Cyanverbindungen des Osmiums. J. Pract. Chem. 1928, 119, 279-286. [CrossRef]

43. Alexander, J.J.; Gray, H.B. Electronic Structures of Hexacyanometalate Complexes. J. Am. Chem. Soc. 1968, 90, 4260-4271. [CrossRef]

44. Manoli, J.-M.; Potvin, C.; Brégeault, J.-M.; Griffith, W.P. Crystal structure of potassium heptacyanorhenate(III) dehydrate. J. Chem. Soc. Dalton Trans. 1980, 192-195. [CrossRef]

45. Teller, R.G.; Bau, R. Crystallographic studies of transition metal hydride complexes. In Structure and Bonding; Springer-Verlag: Berlin, Germany, 1981; Volume 44, pp. 1-82.

46. Moore, D.S.; Robinson, S.D. Hydrido complexes of the transition metals. Chem. Soc. Rev. 1983, 12, 415-452. [CrossRef]

47. McGrady, G.S.; Guilera, G. The Multifarious World of Transition Metal Hydrides. Chem. Soc. Rev. 2003, 32, 383-392. [CrossRef] [PubMed]

48. Glemser, O.; Roesky, H.W.; Hellberg, K.-H.; Werther, H.-H. Darstellung und Eigenschaften von Osmiumheptafluorid. Chem. Ber. 1966, 99, 2652-2662. [CrossRef]

49. Shorafa, H.; Seppelt, K. Osmium(VII) Fluorine Compounds. Inorg. Chem. 2006, 45, 7929-7934. [CrossRef] [PubMed]

50. Srivastava, A.K.; Misra, N. Theoretical investigation on the structure, stability and superhalogen properties of OsFn ( $\mathrm{n}=1-7)$ species. J. Fluorine Chem. 2014, 158, 65-68. [CrossRef]

51. Pedersen, K.S.; Dreiser, J.; Nehrkorn, J.; Gysler, M.; Schau-Magnussen, M.; Schnegg, A.; Holldack, K.; Bittl, R.; Piligkos, S.; Weihe, H.; et al. A linear single-molecule magnet based on $\left[\mathrm{Ru}^{\mathrm{III}}(\mathrm{CN})_{6}\right]^{3-}$. J. Chem. Commun. 2011, 47, 6918-6920. [CrossRef]

52. Dreiser, J.; Pedersen, K.S.; Schnegg, A.; Holldack, K.; Nehrkorn, J.; Sigrist, M.; Tregenna-Piggott, P.; Mutka, H.; Weihe, H.; Mironov, V.S.; et al. Three-axis anisotropic exchange coupling in the single-molecule magnets $\left.\mathrm{NEt}_{4}\left[\mathrm{Mn}_{2}^{\mathrm{III}} \text { (5-Brsalen }\right)_{2}(\mathrm{MeOH})_{2} \mathrm{M}^{\mathrm{III}}(\mathrm{CN})_{6}\right](\mathrm{M}=\mathrm{Ru}, \mathrm{Os})$. Chem. Eur. J. 2013, 19, 3693-3701. [CrossRef] [PubMed]

53. Vostrikova, K.; Homoleptic, E. Osmium Cyanide Complexes: Synthesis and Perspective Application in Molecular Magnetism. In Osmium: Synthesis Characterization and Applications; Wise, G., Ed.; Nova Science Publishers: Hauppauge, NY, USA, 2015; pp. 43-78.

54. Pedersen, K.S.; Sigrist, M.; Weihe, H.; Tregenna-Piggott, P.L.W.; Schau-Magnussen, M.; Dreiser, J.; Mutka, H.; Barra, A.-L.; Bendix, J. Mn ${ }^{\mathrm{III}}$ zero-field splitting parameters and weak exchange interactions in a cyanide-bridged $\left\{\mathrm{Mn}^{\mathrm{III}}-\mathrm{Ir}^{\mathrm{III}}-\mathrm{Mn}^{\mathrm{III}}\right\}$ cluster. Inorg. Chem. Commun. 2012, 24, 24-28. [CrossRef] 